\title{
Evaluation of Plant Growth-Promoting Actinomycetes on Vigna
}

\author{
P. Ponmurugan, V. Elango, A. Sathya, R. Vijayabharathi, \\ and S. Gopalakrishnan
}

\begin{abstract}
The legume genus Vigna are grown in warm temperate and tropical regions globally but are particularly crucial to human nutrition in large parts of tropical Africa and Asia. It can also serve as forage crops. Among the Vigna species, the Asian Vigna has received little research initiatives than African Vigna such as cowpea and mung bean. From the last decade, the research initiatives are getting increased for both the Vigna species in the context of genetic resource analysis and genome mapping. The production status has remained stagnant in many countries due to long list of pest and pathogen attacks and abiotic stresses. Use of plant growthpromoting microbes for improving the productivity of Vigna species is still in its infancy, and there were very few field evaluation studies conducted. This chapter brings an overview of several reports which documented the various facets of plant growth-promoting microbes, particularly of actinomycetes, in increasing growth performance and productivity of Vigna.
\end{abstract}

\section{Keywords}

Vigna - Plant growth promotion - Actinomycetes - Phosphate solubilizers $\bullet$ Burkholderia $\bullet$ Streptomyces

\subsection{Introduction}

P. Ponmurugan $(\bowtie) \cdot \mathrm{V}$. Elango

Department of Biotechnology, K. S. Rangasamy College of Technology, Namakkal District, Tiruchengode

637 215, Tamil Nadu, India

e-mail: drponmurugan@gmail.com

A. Sathya • R. Vijayabharathi • S. Gopalakrishnan International Crops Research Institute for the Semi-Arid Tropics, Patancheru 502 324, Telangana, India
Legumes belonging to the family Fabaceae or Leguminosae are the second most important crops next to cereals among the food crops. Legumes are the third largest family among the flowering plants, consisting of approximately 650 genera and 20,000 species (Doyle 1994). They are the important sources of protein for 
vegetarians and comprise twice the amount on average than cereals. It also provides significant amounts of micronutrients, including iron, zinc, calcium, and vitamins. In addition, legumes are excellent sources of nutraceutical constituents such as phenolics, flavonoids, isoflavones, lignans, and tannins. These compounds have antioxidant, antimutagenic, and anticarcinogenic activities. Hence, their consumption is recommended by several health organizations for a broad spectrum of health benefits (Letreme 2002; Duranti 2006). Along with the nutritional benefits, their accessibility and affordability to lower-income populations and resource-poor people around the world made them to be recognized as "poor man's meat" (Swaminathan 1974). A list of some legumes and their origin is shown in Table 18.1 (Nene 2006).

As one of the strategies of "Green Revolution," high inputs of artificial $\mathrm{N}$ fertilizers into farmlands (up to 100 million tons per year) were used for higher crop productivity. However, they

Table 18.1 Geographical origin and domestication of various pulses grown in Indian subcontinent

\begin{tabular}{|c|c|c|}
\hline Legume & Binomial name & $\begin{array}{l}\text { Geographical origin } \\
\text { and domestication }\end{array}$ \\
\hline Chickpea & $\begin{array}{l}\text { Cicer } \\
\text { arietinum }\end{array}$ & Turkey-Syria \\
\hline $\begin{array}{l}\text { Pigeon } \\
\text { pea }\end{array}$ & Cajanus cajan & India \\
\hline Lentil & Lens culinaris & $\begin{array}{l}\text { Southwest Asia } \\
\text { (Turkey-Cyprus) }\end{array}$ \\
\hline $\begin{array}{l}\text { Black } \\
\text { gram }\end{array}$ & Vigna mungo & Indian subcontinent \\
\hline $\begin{array}{l}\text { Green } \\
\text { gram }\end{array}$ & Vigna radiata & Indian subcontinent \\
\hline $\begin{array}{l}\text { Lablab } \\
\text { bean }\end{array}$ & $\begin{array}{l}\text { Lablab } \\
\text { purpureus }\end{array}$ & Indian subcontinent \\
\hline $\begin{array}{l}\text { Moth } \\
\text { bean }\end{array}$ & $\begin{array}{l}\text { Vigna } \\
\text { aconitifolia }\end{array}$ & Indian subcontinent \\
\hline $\begin{array}{l}\text { Horse } \\
\text { gram }\end{array}$ & $\begin{array}{l}\text { Macrotyloma } \\
\text { uniflorum }\end{array}$ & Indian subcontinent \\
\hline Pea & Pisum sativum & Southern Europe \\
\hline $\begin{array}{l}\text { Grass } \\
\text { pea }\end{array}$ & $\begin{array}{l}\text { Lathyrus } \\
\text { sativus }\end{array}$ & Southern Europe \\
\hline Cowpea & $\begin{array}{l}\text { Vigna } \\
\text { unguiculata }\end{array}$ & West Africa \\
\hline $\begin{array}{l}\text { Faba } \\
\text { bean }\end{array}$ & Vicia faba & West Asia \\
\hline
\end{tabular}

Source: Nene (2006) could not serve for sustainable aspect of food production as they are produced using energy from fossil fuels. On the other end, biological nitrogen fixation (BNF) accounts for about $65 \%$ of $\mathrm{N}$ currently used in agriculture. Due to the N-fixing ability of legumes, they are used in crop rotations which have a positive impact on soil fertility and subsequent crop productivity. Legumes meet their own $\mathrm{N}$ needs via BNF, and major part of fixed $\mathrm{N}$ is harvested as grains, while the soil and the succeeding crops benefitted by $\mathrm{N}$ in the form of root and shoot residues (Bhattacharyya and Jha 2012). Though nonsymbiotic systems are also contributing for $\mathrm{N}$ fixation, the contribution of legume-rhizobia symbiosis (13-360 $\left.\mathrm{kg} \mathrm{N} \mathrm{ha}^{-1}\right)$ is far greater than the nonsymbiotic systems (10-160 $\mathrm{kg} \mathrm{N}^{-1}$ ) (Bohlool et al. 1992). This leads to the substantial reduction of the $\mathrm{N}$ requirement from external sources. The quantity of $\mathrm{N}$ fixed by some legumes is shown in Table 18.2. Hence, the production and consumption of more legumes in human diets could aid in the reduction of global warming, eutrophication, acidification, and land degradation besides reducing protein-energy malnutrition and micronutrient deficiencies in developing countries (Davis et al. 2010).

Even though legumes are high in numbers, selected cash crops such as soybean, pea, and cowpea alone have been exploited. Severe genetic erosion of the legume species is occurring currently due to anthropogenic activities and also due to the introduction of genetically modified crops. A total of 2206 legume species have been listed in International Union for Conservation of Nature (IUCN) red list (Walters and Gillet 1998). In addition, the production of

Table 18.2 Reported quantum of nitrogen fixed by legumes

\begin{tabular}{l|c}
\hline Legume & Fixed nitrogen quantity $\left(\mathrm{kg} \mathrm{N} \mathrm{ha}^{-1}\right)$ \\
\hline Soybean & $33-643$ \\
\hline Groundnut & $126-319$ \\
\hline Black gram & $125-143$ \\
\hline Cowpea & $25-100$ \\
\hline Pigeon pea & $77-92$ \\
\hline Green gram & $71-74$ \\
\hline
\end{tabular}

Source: Peoples and Crasswell (1992) 
common legumes has remained unmet with the consumption rate (Ali and Kumar 2000). The crop yield is constrained due to limited adaptability of available cultivars and by a long list of pathogen attacks like powdery mildew, downy mildew, rust, Ascochyta blight, Botrytis gray mold, white mold, damping-off, anthracnoses, root rot, collar rot, and vascular wilts and pest attacks from chewing and sap-sucking insects followed by attacks from parasitic weeds, viruses, bacteria, and nematodes (Rubiales et al. 2015).

Pesticides and fertilizers of chemical origin can overcome yield losses by pathogen and pest attacks and increase the productivity. However, it also has safety risks, loss of natural enemies, outbreaks of secondary pests, insect resistance, environmental contamination, and biodiversity loss (Lacey and Shapiro-Ilan 2008). The increasing costs, negative effects of pesticides, fertilizers, and consumer preference on pesticidefree food products necessitate the idea of biological options for crop protection and production. Usage of animal manure, crop residues, composts, and microorganisms (Rhizobium, Azotobacter, Azospirillum, blue-green algae, Pseudomonas, Bacillus, and actinomycetes) can play key roles as it provides natural nutrition, reduces the use of inorganic fertilizers, develops biodiversity, increases soil biological activity, maintains soil physical properties, and improves environmental health (Hue and Silva 2000; Vessey 2003). This book chapter will bring a note on one of the legume genus Vigna and the importance of microbial inoculum, in particular actinomycetes, in its exploration.

\subsection{Vigna}

The genus Vigna are hot weather herbaceous legumes first evolved in Africa as the major species (Vaillancourt et al. 1993). Recent report of Thulin et al. (2004) further suggests this through molecular studies that Vigna may have evolved from Wajira, the African genus as it is basal compared to Vigna and Phaseolus. Detailed description on taxonomy of Vigna documents that there are 98 species and six subgenera in which the subgenus Vigna has the highest number of species of about 38 (Maxted et al. 2006). Most of the Vigna species are nutritionally enriched and are particularly crucial to human and animal nutrition in large parts of tropical Africa and Asia (Vijayakumari et al. 1998; Ullah et al. 2014). However, the domesticated Vigna species such as cowpea (Vigna unguiculata) and mung bean (Vigna radiata) are vital in terms of production. The production stands at about 4.5 million metric tons $/ 10$ million ha for the former and is $2.5-3$ million metric tons $/ 5$ million ha for the latter species (Tomooka et al. 2005). Other species of interest in specific countries are listed in Table 18.3. A complete description on genetic resources of available Vigna species was given by Tomooka et al. (2011), and it is understood that Vigna has huge biodiversity of wild and cultivated species.

The genus Vigna is also peculiar for its resistance against many abiotic stresses. Reports of Iwasaki et al. (2002) and Singh et al. (2015) registered tolerance of Vigna species such as $V$. umbellata and $V$. unguiculata for the heavy metals $\mathrm{Al}$ and $\mathrm{Mn}$. They are well tolerant for salinity (Sehrawat et al. 2015; Win et al. 2011), and many crops were developed with enhanced salt tolerance using proline biosynthetic pathway genes PSCS and PSCSF129A of $V$. aconitifolia and the list is given in Table 18.4. Besides this, recent report of De-Abreu et al. (2014) brought the involvement of various proteins for salt stress tolerance in $V$. unguiculata through proteomic approaches. The proteome data registered that cowpea cultivars adopt different strategies to

Table 18.3 Representatives of other Vigna species of interest and their producing countries

\begin{tabular}{l|l|l}
\hline $\begin{array}{l}\text { Common } \\
\text { name }\end{array}$ & $\begin{array}{l}\text { Binomial } \\
\text { name }\end{array}$ & Producing country \\
\hline $\begin{array}{l}\text { Azuki bean } \\
\text { Rice bean }\end{array}$ & V. angularis & China and Japan \\
\hline Moth bean & V. aconitifolia & $\begin{array}{l}\text { Northern India and } \\
\text { Southeast Asia }\end{array}$ \\
\hline $\begin{array}{l}\text { Bambara } \\
\text { groundnut }\end{array}$ & V. subterranea & Africa \\
\hline
\end{tabular}


Table 18.4 Genes of $V$. aconitifolia used for developing transgenic plants and its developed traits

\begin{tabular}{|c|c|c|}
\hline Genes $^{\mathrm{a}}$ & Target plant & $\begin{array}{l}\text { Enhanced tolerance and } \\
\text { phenotype of transgenic } \\
\text { plants }\end{array}$ \\
\hline \multirow[t]{11}{*}{ PSCS } & \multirow[t]{2}{*}{ Tobacco } & $\begin{array}{l}\text { Enhanced biomass, } \\
\text { flower and seed } \\
\text { development }\end{array}$ \\
\hline & & $\begin{array}{l}\text { Proline accumulation } \\
\text { and increased enzyme } \\
\text { activities }\end{array}$ \\
\hline & Wheat & $\begin{array}{l}\text { Enhanced proline } \\
\text { accumulation }\end{array}$ \\
\hline & Carrot & Salt stress tolerance \\
\hline & $\begin{array}{l}\text { Larix } \\
\text { leptoeuripaea }\end{array}$ & $\begin{array}{l}\text { Enhanced tolerance for } \\
\text { cold and salinity }\end{array}$ \\
\hline & Medicago & $\begin{array}{l}\text { Enhanced proline } \\
\text { accumulation }\end{array}$ \\
\hline & Chickpea & $\begin{array}{l}\text { Enhanced proline } \\
\text { accumulation and salt } \\
\text { stress tolerance }\end{array}$ \\
\hline & Sugarcane & $\begin{array}{l}\text { Enhanced proline } \\
\text { accumulation and salt } \\
\text { stress tolerance, lesser } \\
\text { oxidative damage }\end{array}$ \\
\hline & \multirow[t]{4}{*}{ Rice } & $\begin{array}{l}\text { Enhanced salt stress } \\
\text { tolerance }\end{array}$ \\
\hline & & $\begin{array}{l}\text { Enhanced salt and } \\
\text { drought stress tolerance }\end{array}$ \\
\hline & & $\begin{array}{l}\text { Enhanced salt stress } \\
\text { tolerance up to } 200 \mathrm{mM} \\
\mathrm{NaCl}\end{array}$ \\
\hline \multirow[t]{2}{*}{ PSCSF129A } & & $\begin{array}{l}\text { Enhanced proline } \\
\text { accumulation and salt } \\
\text { stress tolerance }\end{array}$ \\
\hline & Pigeon pea & $\begin{array}{l}\text { Enhanced proline } \\
\text { accumulation and salt } \\
\text { stress tolerance }\end{array}$ \\
\hline
\end{tabular}

Source: Kumar et al. (2015)

${ }^{\mathrm{a}}$ Genes involved in proline biosynthetic pathway

alleviate salt stress. In salt-tolerant cultivar Pitiúba, proteins involved in photosynthesis and energy metabolism, such as rubisco activase, ribulose-5-phosphate kinase (Ru5PK), glycine decarboxylase, and oxygen-evolving enhancer (OEE) protein 2, were profoundly expressed. On the other hand, in salt-sensitive cultivar $\mathrm{TVu}$, downregulation of OEE protein 1, Mn-stabilizing protein-II, carbonic anhydrase, and Ru5PK was noticed which led to energy reduction and hence decline in plant growth.
The African Vigna, cowpea, is a mandate crop of the International Institute of Tropical Agriculture (IITA) and subsequently receiving considerable attention from the international agricultural research community by the initiatives such as Cowpea Genomics Initiative (Chen et al. 2007), Bean/Cowpea Collaborative Research Support Program (http://www.isp.msu.edu/CRSP), Generation Challenge Programme (http://www. generationcp.org), and Network for the Genetic Improvement of Cowpea for Africa - NGICA (http://www.entm.purdue.edu/NGICA/). However, the Asian Vigna is called as "slow runners" by Borlaug (1973) as its research and development is not focused by international institutes. However, the importance for the Asian Vigna has recently increased with some significant scientific advances in particular to genetic resource analysis and genome mapping (Kaga et al. 2005, 2008; Tomooka et al. 2006). A detailed review by Nair et al. (2013) on one of the Asian Vigna mung bean conveys its key role in enhancing the food and nutritional security via breeding and other agronomic practices. Besides the magnitude of research attention, seed yield of cowpea and other Asian and African Vigna species remains low in farmer's fields except few countries (Singh 2005; Matsunaga et al. 2008; Saxena 2011) due to various biotic and abiotic stresses (Kumar and Kumar 2015).

\subsection{Plant Growth-Promoting Microbes}

Microbes with agriculturally favorable traits categorized as plant growth-promoting (PGP) microbes are of great importance in agricultural practice. In case of legumes, the practice of mixing natural rhizospheric soil with seeds is the recommended method of legume inoculation during the nineteenth century. The reason behind this practice is that rhizospheric soil is an enriched source of microorganisms (10-100folds than the bulk soil) such as bacteria, fungus, algae, and protozoa. Rhizospheric soil is usually rich in nutrients than bulk soil as it accumulates 
organic acids, amino acids, fatty acids, phenols, nucleotides, putrescine, sterols, vitamins, sugars, and plant growth regulators/promoters released from the root exudates (Uren 2007).

The rhizobacteria were categorized depending on their proximity to the roots as (i) bacteria living near the roots (rhizosphere), (ii) bacteria colonizing the root surface (rhizoplane), (iii) bacteria residing in root tissue (endophytes), and (iv) bacteria living inside cells in specialized root structures or nodules; the latter group is further divided into two groups - the legumeassociated rhizobia and the woody plantassociated Frankia sp. Microbes belonging to any of these categories and improving plant growth either through direct ( $\mathrm{N}$ fixation, phosphate $(\mathrm{P})$ solubilization, iron chelation, and phytohormone production) or indirect (suppression of plant pathogens and induction of host plant resistance against phytopathogens and abiotic stresses) mechanisms are referred as plant growth-promoting rhizobacteria (PGPR). This includes the genera Bacillus, Pseudomonas, Erwinia, Caulobacter, Serratia, Arthrobacter, Flavobacterium, Chromobacterium, Agrobacterium, Rhizobium, Streptomyces, and Rhodococcus (Glick 1995).

The microbial flora present in soil and other sources such as vermicompost and farmyard manure (FYM) plays an important role in plant growth promotion. Application of organic manure such as FYM and phosphate solubilizer significantly increased the rhizospheric microbial flora and yield of green gram (Chesti and Tahir 2012). Application of microbial species isolated from vermicompost enhanced the growth of green gram in terms of shoot length, root length, number of leaves, and yield (Gopinath and Prakash 2014; Geetha et al. 2014). Rhizobium was found to enhance germination of seed of green gram (Vaishali et al. 2014). Fernandes and Bhalerao (2015) reported that the seed treatment of green gram with Azotobacter enhanced the plant morphological and biochemical parameters. As compared to green gram, the combination of Rhizobium, phosphobacteria, and Azospirillum increased the plant growth, morphology, and biochemical constituents of cowpea (Sivakumar et al. 2013). Besides this, indirect growth-promoting effects were also observed. Aswini and Giri (2014) evaluated Trichoderma viride, Bacillus subtilis, and Pseudomonas fluorescence for the control of seedborne root diseases in green gram and achieved $86 \%, 65 \%$, and $47 \%$ control, respectively. Similarly, a combination of $T$. viride and $P$. fluorescence was utilized to control green gram root pathogen Macrophomina phaseolina in vitro, under glasshouse and field conditions. In this combination, the defense-related enzymes of green gram such as peroxidase, polyphenol oxidase, and phenylalanine ammonia-lyase were significantly increased (Thilagavathi et al. 2007). In addition, Siddiqui and Mahmood (1999) reported that the microbes such as Streptomyces, Agrobacterium, Alcaligenes, Bacillus, Clostridium, Desulfovibrio, Pseudomonas, and Serratia were used for the control of nematodes in soil.

Among the PGP microbes, actinobacteria are one of the key groups because, as per the literature survey, they account for $\sim 60 \%$ of new antibiotics among the microbial compounds of about 60-80,000. In specific, the single genus Streptomyces is the major producer of secondary metabolites (39\% of all microbial metabolites) (Berdy 2012). Streptomyces spp. were reported as potential biocontrol agents against root fungal pathogens (Bhattacharyya and Jha 2012). Actinomycetes isolated form herbal vermicompost including Streptomyces tsusimaensis, Streptomyces caviscabies, Streptomyces setonii, Streptomyces africanus, and a Streptomyces sp. were found to reduce disease symptoms up to $20 \%$ on Fusarium wilt of chickpea grown in wilt-sick plots (Gopalakrishnan et al. 2011). But the potential of actinomycete group has not been much explored in Vigna in specific at field conditions. Use of such microbial inoculum in exploring the productivity of Vigna is discussed below. 


\subsection{Role of Phosphate Solubilizers on Vigna}

Plant $\mathrm{P}$ availability is limited particularly in tropical soils, despite its high soil content (Collavino et al. 2010). Usually, most soil P exists as insoluble metal chelates and requires substantial amounts of chemical phosphate fertilizers which are rapidly converted into insoluble $\mathrm{P}$ sources. This leads to regular application of $\mathrm{P}$ fertilizers, which are costly and environmentally undesirable (Vassilev et al. 2006). It is noted that unavailability of $\mathrm{P}$ has more influences on growth performance of Vigna because tropical soil is the optimal soil for growing Vigna species. In this context, microbial solubilization of soilinsoluble $\mathrm{P}$ into soluble forms is considered by various researchers. Phosphate-solubilizing bacteria (PSBs) belonging to the genera Bacillus, Pseudomonas, Xanthomonas, and Serratia enhanced the nodule, root, and shoot parameters of green gram under greenhouse conditions (Vikram and Hamzehzarghani 2008). Microbes with the phosphate-solubilizing potential and additional trait of phytohormone production are other key resources. This was noticed by Muthezhilan et al. (2012) using Pseudomonas sp. AMET1148 for increased shoot and root length on $V$. radiata and $V$. mungo. Shahab et al. (2009) also noticed similar effects in $V$. radiata by the inoculation of PSB Pseudomonas aeruginosa CMG860 with additional capacity of producing auxin (IAA, 57-288 $\mu \mathrm{g} / \mathrm{ml}$; IBA, 22-34 $\mu \mathrm{g} / \mathrm{ml})$. Nonsymbiotic PGPR belong to Pseudomonas, Escherichia, Micrococcus, and Staphylococcus with IAA-producing capacity $(1.16-8.22 \mu \mathrm{g} / \mathrm{ml})$, and other PGP traits such as $\mathrm{P}$ solubilization and siderophore or hydrogen cyanide production are evaluated for growthpromoting effects of $V$. radiata. Significant positive correlation was noticed for bacterial IAA production and endogenous IAA content of roots $(r=0.969 ; \quad P=0.01)$ and leaves ( $r=0.905 ; P=0.01)$ under axenic conditions. Bacterization of $V$. radiata seeds significantly enhanced shoot length (up to $48 \%$ ) and shoot biomass (up to $43 \%$ ) under axenic conditions. Bacterial strains applied under wire house conditions also improved shoot length, pod number, and grain weight up to $58 \%, 65 \%$, and $17 \%$, respectively, over the control treatments. It is understood that free-living PGPR have the ability to influence endogenous IAA content and growth of leguminous plants (Ali et al. 2010).

Zaidi and Khan (2006) studied the effect of microbial treatment including PSB (B. subtilis), phosphate-solubilizing fungus (Aspergillus awamori), and AM fungus (Glomus fasciculatum) along with nitrogen-fixing Bradyrhizobium sp. (Vigna) on V. radiata under glasshouse conditions. The triple inoculation of AM fungus, Bradyrhizobium sp., and B. subtilis significantly increased dry matter yield, chlorophyll content in foliage, and $\mathrm{N}$ and $\mathrm{P}$ uptake along with the seed yield of $24 \%$ than the control treatment. Nodule occupancy was observed between 77 and $96 \%$ but with a greater variation in the rhizobial populations. In a similar study, two potential PSBs, Pantoea agglomerans and Burkholderia anthina, with the maximum P solubilization of $720 \mu \mathrm{g} / \mathrm{ml}$ were identified among the 31 PSB isolates. Inoculation of these $\mathrm{P}$ solubilizers enhanced shoot and root length, shoot and root dry matter, and $\mathrm{P}$ uptake of $V$. radiata under greenhouse conditions (Walpola and Yoon 2013). Benefit of microbial co-inoculation is further supported by Bahadur and Tiwari (2014) who studied the effect of nutrient management in mung bean through sulfur (S) and biofertilizers. Though significant increase of growth performance was noticed on $S$ treatment, it decreased the soil PSB and actinomycete population. Co-inoculation of Rhizobium and PSB showed significant growth response along with the significant increase of microbial counts for total bacterial population (41.7 $\times 10^{6} / \mathrm{g}$ soil), Rhizobium-like organism population (13.9 $\times 10^{3} / \mathrm{g}$ soil), and Azotobacter population $\left(12 \times 10^{3} / \mathrm{g}\right.$ soil $)$. 


\subsection{Role of Siderophore Producers on Vigna}

Iron, an essential micronutrient for plants, is present in soils ranging from 0.2 to $55 \%$ $(20,000-550,000 \mathrm{mg} / \mathrm{kg})$ and occurs as either the divalent (ferrous or $\mathrm{Fe}^{2+}$ ) or trivalent (ferric or $\mathrm{Fe}^{3+}$ ) forms which is determined by redox potential of the soil and the availability of other minerals (Bodek et al. 1988). Under aerobic environments, iron exists as insoluble hydroxides and oxyhydroxides, which are not accessible to both plants and microbes. Generally, microbes have the ability to synthesis low molecular weight compounds called siderophores which are capable of sequestering $\mathrm{Fe}^{3}$ and also other metals at high affinity and influence their availability to plants. In addition, the siderophores help for antagonistic activity by depriving the availability of $\mathrm{Fe}$ to the pathogens (Rajkumar et al. 2010). Sharma and Johri (2003) and Sharma et al. (2003) observed that inoculation of siderophore-producing Pseudomonas sp. GRP3 is documented to reduce chlorosis, the iron deficiency symptom in $V$. radiata under pot conditions, with and without iron-limiting nutritional status. Significant increase of chlorophyll content and catalase and peroxidase, the key protoheme enzymes, was noticed. This indicates net physiologically available iron to the plant. In a study by Sindhu et al. (1999), Pseudomonas sp. was isolated from the rhizosphere of $V$. radiata with a wide range of antifungal activities against Aspergillus sp., Curvularia sp., Fusarium oxysporum, and Rhizoctonia solani in vitro. Culturing with Fe-deficient succinate medium, Luria-Bertani and King's B medium, suggested that the antifungal activity was supported in two ways, by competing for nutrients especially through siderophore and by producing antifungal metabolites. Co-inoculation of green gram with these antagonistic Pseudomonas MRS13 and MRS16 and Bradyrhizobium sp. (Vigna) S24 registered a significant increase in nodule weight, plant dry weight, and total plant $\mathrm{N}$ as compared to single inoculation with Bradyrhizobium S24. This suggests that the nodule-promoting effects of Pseudomonas sp. lead to an increase in symbiotic $\mathrm{N}$ fixation and plant growth. In a similar study, Saxena (2010)documented antifungal activity of $P$. fluorescens BAM-4, Burkholderia cepacia BAM-6, and B. cepacia BAM-12 isolated from the rhizosphere of $V$. radiata against a range of phytopathogenic fungi. The antagonistic activity might be exerted by siderophores (BAM-4 and BAM-6 strains) and chitinase (all the three strains). Morphological abnormalities of pathogens such as fragmentation, swelling, perforation, and lysis of hyphae were confirmed by scanning electron microscopic images. Bacterization with these isolates provided protection against Macrophomina phaseolina and also enhanced seed germination, shoot length, shoot fresh and dry weight, root length, root fresh and dry weight, leaf area, and rhizosphere colonization. On par with the control treatments, yield parameters such as pods, number of seeds, and grain yield per plant are also significantly enhanced. Co-inoculation of Pseudomonas along with Bradyrhizobium reduced the disease symptoms induced by Rhizoctonia solani in green gram under greenhouse conditions. The nodule parameters and vegetative biomass are enhanced in infected plants also (Sahu and Sindhu 2011).

Actinomycetes, one of the key biocontrol agents, use siderophores as one of the disease control mechanisms. Siderophores such as desferrioxamine B were produced by Streptomyces pilosus and Streptomyces coelicolor, desferrioxamine E by $S$. coelicolor (Jurkevitch et al. 1992), and peucechelin by Streptomyces peucetius (Kodani et al. 2015). Streptomyces griseoviridis is available in the market as a biocontrol agent with trade name of Mycostop, Subtilex, and System3 (Kumar and Pundhir 2009). Though some microbes are evaluated for disease of Vigna species, the siderophoreproducing actinomycetes were not studied extensively. Further studies in this context will bring potential biocontrol agents for diseases in Vigna. 


\subsection{Role of PGPR Under Stress Conditions on Vigna}

The gaseous plant hormone ethylene plays a key role in plant development, from seed germination to fruit ripening. However, its triggered production during stress environments ends in plant's premature death. Many rhizospheric microbes are known to control ethylene through ACC deaminase (ACCd) which cleaves ACC, the immediate precursor of ethylene into ammonia and $\alpha$-ketobutyrate, and helps in alleviating stress consequences of crops (Penrose and Glick 2003). Strains, such as Rhizobium leguminosarum bv. viciae, Rhizobium hedysari, Rhizobium japonicum, Mesorhizobium loti, Bradyrhizobium japonicum, Sinorhizobium meliloti, Bacillus sp., and Pseudomonas sp., had been known to produce ACC deaminase (Duan et al. 2009; Glick 2014; Hafeez et al. 2008; Uchiumi et al. 2004). Inoculation with these bacteria had shown to promote root elongation, shoot growth, enhanced rhizobial nodulation, and mineral uptake (Glick 2012). Shaharoona et al. (2006) observed the similar traits by inoculation of a rhizobacteria possessing ACC deaminase activity isolated from maize rhizosphere along with the co-inoculation of Bradyrhizobium on mung bean under pot conditions. Besides the free-living microbes, Jaemsaeng et al. (2013) documented the similar influences of endophytes with ACC deaminase activity. Sixteen strains among the 67 endophytic actinomycetes showed ability of ACC deaminase production and the expression of $\operatorname{acd} \mathrm{S}$, the ACC deaminase synthetic gene. Native endophytic Streptomyces sp. GMKU336 with ACC deaminase and a mutant without ACC deaminase activity was individually inoculated into mung bean plants grown under stress conditions of salinity and flooding. Mung bean plants inoculated with the wild type could survive under salinity at $100 \mathrm{mM}$ $\mathrm{NaCl}$ and flooding stresses and significantly enhanced root/shoot growth and leaf chlorophyll content than un-inoculated and ACC deaminasedeficient mutant treatments. The actinobacterial strains such as Micrococcus, Corynebacterium,
Arthrobacter, Rhodococcus, and Streptomyces spp. with exemplified ACC deaminase activity were found to improve plant growth in other crops also (Palaniyandi et al. 2013).

A nickel (Ni)-resistant Streptomyces acidiscabies E13 simultaneously produced three different hydroxamate siderophores, and it was observed that they can bind nickel besides binding with Fe. Culture filtrates containing hydroxamate siderophores significantly increased cowpea growth parameters, irrespective of the iron status of the plants, under Ni stress. The presence of reduced iron was found to be high in siderophore-containing treatments in the presence of Ni. Measurements of $\mathrm{Fe}$ and $\mathrm{Ni}$ contents of cowpea roots and shoots indicated that the siderophore-mediated plant growth promotion reported here involves the simultaneous inhibition of Ni uptake and solubilization and supply of Fe to plants (Dimkpa et al. 2008).

Ahmad et al. (2012a) conducted a pot trial to evaluate the effect of combined application of Rhizobium phaseoli (M6 and M9) and PGPR (Pseudomonas syringae Mk1, P. fluorescens Mk20, and P. fluorescens Biotype G, Mk25) to improve the productivity of mung bean under salt-stressed conditions. Inoculation with either rhizobia or PGPR alone enhanced growth performance and yield components significantly. However, the co-inoculation of rhizobia and PGPR was more effective by increased shoot fresh weight (145\%), root fresh weight (173\%), number of pods/plant $(150 \%)$, pod fresh weight $(182 \%)$, total dry matter $(269 \%)$, relative water content (19\%), water use efficiency $(51 \%), \mathrm{K}$ concentration in leaves $(33 \%), \mathrm{Na}$ concentration in leaves (56\%), and nitrogen concentration in grains of mung bean (99\%), compared with the un-inoculated control.

Pesticide accumulation in soils has occurred as result of repeated applications beyond the recommended doses and by their slow degradation rate. It affects plant growth by altering plant root's architecture and transformation of microbial compounds to plants and vice versa. Besides this, growth and activity of free-living or 
endophytic nitrogen-fixing bacteria have also been affected (Mathur 1999). Several studies have documented the effects of various pesticides on the reduction of microbial diversity and density on various soil types (El Abyad and Abou-Taleb 1985; Moorma 1988; Martinez-Toledo et al. 1996). But several microbes have the capacity to degrade the pesticides and promote plant growth (Kumar et al. 1996). Ahemad and Khan (2011) evaluated the effect of fungicides (hexaconazole, kitazin, and metalaxyl), insecticides (imidacloprid and thiamethoxam), and herbicides (metribuzin and glyphosate), at the recommended and the higher dose rates on PGP activities of Bradyrhizobium sp. MRM6 isolated from nodules of green gram plants under in vitro conditions. The highest toxicity was observed at three times higher recommended doses along with decline of PGP traits. In further studies, they observed that a PGP $P$. aeruginosa PS1 with tebuconazole tolerance increased the growth parameters of the green gram plants, two and three times the recommended field rate of tebuconazole. The increased parameters are root $\mathrm{N}$, shoot $\mathrm{N}$, root $\mathrm{P}$, shoot $\mathrm{P}$, and seed yield (Ahemad and Khan 2012b).

\subsection{Conclusion}

The knowledge of using of microbial inoculum has started many centuries ago as an agricultural practice, but its application at field level is very low in the current scenario. This is due to variations in the microbial activity under field conditions with the complex interaction of soil nutrients, climatic factors, and stress conditions. In the context of Vigna, very limited numbers of reports are available for the use of PGPR and also under field conditions, and the available reports can bring only a bird's-eye view. Despite this, actinobacteria, one of the key groups in PGPR, are not extensively studied in Vigna, though it was evaluated in many leguminous crops such as pea, chickpea, and soybean. So research initiatives to explore the potential of PGP actinobacteria have to be considered, and the strains should be evaluated in intensive field trials for developing biofertilizers to improve the productivity of Vigna.

\section{References}

Ahemad M, Khan MS (2011) Effect of pesticides on plant growth-promoting traits of green gram symbiont, Bradyrhizobium sp. strain MRM6. Bull Environ Contam Toxicol 86:384-388

Ahemad M, Khan MS (2012) Alleviation of fungicideinduced phytotoxicity in green gram [Vigna radiata (L.) Wilczek] using fungicide-tolerant and plant growth-promoting Pseudomonas strain. Saudi J Biol Sci 19:451-459

Ahmad M, Zahir ZA, Asghar HN, Arshad M (2012) The combined application of rhizobial strains and plant growth-promoting rhizobacteria improves growth and productivity of mung bean (Vigna radiata L.) under salt-stressed conditions. Ann Microbiol 62: 1321-1330

Ali M, Kumar S (2000) Problems and prospects of pulses research in India. Indian Farm 50:4-13

Ali B, Sabri AN, Hasnain S (2010) Rhizobacterial potential to alter auxin content and growth of Vigna radiata (L.). World J Microbiol Biotechnol 26:1379-1384

Aswini C, Giri GK (2014) Control of seed-borne fungi in green gram and black gram through bioagents. Int $\mathrm{J}$ Appl Biol Pharm Tech 5(3):168-170

Bahadur L, Tiwari DD (2014) Nutrient management in mung bean (Vigna radiata 1 .) through sulphur and biofertilizers. Legum Res 37:180-187

Berdy J (2012) Thoughts and facts about antibiotics: where we are now and where we are heading. J Antibiot 65:385-395

Bhattacharyya PN, Jha DK (2012) Plant growthpromoting rhizobacteria (PGPR): emergence in agriculture. World J Microbiol Biotechnol 28:1327-1350

Bodek I, Lyman WJ, Reehl WF, Rosenblatt DH (1988) Environmental inorganic chemistry: properties, processes and estimation methods. In: Walton BT, Conway RA (eds) SETAC special publication series. Pergamon Press, New York

Bohlool BB, Ladha JK, Garrity DP, George T (1992) Biological nitrogen fixation for sustainable agriculture: a perspective. Plant Soil 141:1-11

Borlaug N (1973) Building a protein revolution on grain legumes. In: Milner M (ed) Nutritional improvement of food legumes by breeding. Protein Advisory Group of the Unitied Nations, New York, pp 7-11

Chen X, Laudeman TW, Rushton PJ, Spraggins TA, Timko MP (2007) CGKB: an annotation knowledge base for cowpea (Vigna unguiculata L.) methylation filtered genomic genespace sequences. BMC Bioinforma 8:129-137

Chesti MH, Tahir A (2012) Rhizospheric micro-flora, nutrient availability and yield of green gram (Vigna 
radiata L.) as influenced by organic manures, phosphate solubilizers and phosphorus levels in alfisols. J Ind Soc Soil Sci 60(1):25-29

Collavino MM, Sansberro PA, Mroginski LA, Aguilar OM (2010) Comparison of in vitro solubilization activity of diverse phosphate-solubilizing bacteria native to acid soil and their ability to promote Phaseolus vulgaris growth. Biol Fertil Soils 46: $727-738$

Davis J, Sonesson U, Baumgartner DU, Nemecek T (2010) Environmental impact of four meals with different protein sources: case studies in Spain and Sweden. Food Res Int 43:1874-1884

De-Abreu CE, Araújo GS, Moreira MAC, Costa JH, Hde LB, Moreno FB, Prisco JT, Gomes-Filho E (2014) Proteomic analysis of salt stress and recovery in leaves of Vigna unguiculata cultivars differing in salt tolerance. Plant Cell Rep 33:1289-1306

Dimkpa C, Svatos A, Merten D, Chel GB, Erika K (2008) Hydroxamate siderophores produced by Streptomyces acidiscabies E13 bind nickel and promote growth in cowpea (Vigna unguiculata L.) under nickel stress. Can J Microbiol 54:163-172

Doyle JJ (1994) Phylogeny of the legume family: an approach to understanding the origins of nodulation. Ann Rev Ecol Evol Syst 25:325-349

Duan J, Muller KM, Charles TC, Vesely S, Glick BR (2009) 1-Aminocyclopropane-1carboxylate (ACC) deaminase gene in Rhizobium from Southern Saskatchewan. Microb Ecol 57:423-436

Duranti M (2006) Grain legume proteins and nutraceutical properties. Fitoterapia 77:67-82

El Abyad MS, Abou-Taleb AM (1985) Effects of the herbicides simazine and bromophenoxim on the microflora of two soil types in Egypt. Zentralbl Mikrobiol 40:607-619

Fernandes P, Bhalerao SA (2015) Effect of biofertilizer on the growth of mung bean Vigna radiata (L, Wilczek). Int Res J Sci Eng 3(2):51-54

Geetha K, Venkatesham E, Hindumathi A, Bhadraiah B (2014) Isolation, screening and characterization of plant growth-promoting bacteria and their effect on Vigna radiata (L.) Wilezek. Int J Curr Microbiol Appl Sci 3(6):799-899

Glick BR (1995) The enhancement of plant growth by free-living bacteria. Can J Microbiol 41:109-117

Glick BR (2012) Plant growth-promoting bacteria: mechanisms and applications. Scientifica, Article ID 963401

Glick BR (2014) Bacteria with ACC deaminase can promote plant growth and help to feed the world. Microbiol Res 169:30-39

Gopalakrishnan S, Pande S, Sharma M, Humayun P, Kiran BK, Sandeep D, Vidya MS, Deepthi K, Rupela $\mathrm{O}$ (2011) Evaluation of actinomycete isolates obtained from herbal vermicompost for biological control of Fusarium wilt of chickpea. Crop Prot 30:1070-1078

Gopinath R, Prakash M (2014) Isolation of plant growthpromoting rhizobacteria (PGPR) from vermicompost and effect on growth of green gram (Vigna radiata L.). Int J Curr Microbiol App Sci 3(7):1072-1081

Hafeez FY, Hassan Z, Naeem F, Basher A, Kiran A, Khan SA, Malik KA (2008) Rhizobium leguminosarum bv. viciae strain LC-31: analysis of novel bacteriocin and ACC-deaminase gene(s). In: Dakora FD, Chimphango SBM, Valentine AJ, Elmerich C, Newton WE (eds) Biological nitrogen fixation: towards poverty alleviation through sustainable agriculture. Springer, Dordrecht, pp 247-248

Hue NV, Silva JA (2000) Organic soil amendments for sustainable agriculture: organic sources of nitrogen, phosphorus and potassium. In: Silva JA, Uchida R (eds) Plant nutrient management in Hawaii's soils, approaches for tropical and subtropical agriculture. College of Tropical Agriculture and Human Resources, University of Hawaii, Manoa

Iwasaki K, Maier Fecht PM, Horst WJ (2002) Effects of silicon supply on apoplastic manganese concentrations in leaves and their relation to manganese tolerance in cowpea (Vigna unguiculata (L.) Walp.). Plant Soil 238:281-288

Jaemsaeng R, Indananda C, Thamchaipenet A (2013) 1-aminocyclopropane-1-carboxylate (Acc) deaminase producing endophytic Streptomyces increases tolerance of stresses in mung bean plants. Seminar on atural Resources Adaptation to the Global Climate Change: Extended abstracts, Bangkok, pp 138-141

Jurkevitch E, Hadar Y, Chen Y (1992) Differential siderophore utilization and iron uptake by soil and rhizosphere bacteria. Appl Environ Microbiol 58(1): 119-124

Kaga A, Vaughan DA, Tomooka N (2005) Molecular markers in plant breeding and crop improvement of Vigna. In: Lorz H, Wenzel G (eds) Biotechnology in agriculture and forestry, vol 55, Molecular markers in plant breeding and crop improvement. Springer, Heidelberg, pp 171-187

Kaga A, Isemura T, Tomooka N, Vaughan DA (2008) The domestication of the azuki bean (Vigna angularis). Genetics 178:1013-1036

Kodani S, Komaki H, Suzuki M, Kobayakawa F, Hemmi H (2015) Structure determination of a siderophore peucechelin from Streptomyces peucetius. BioMetals 28(5):791-801

Kumar A, Kumar A (2015) Effect of abiotic and biotic factors on incidence of pests and predator in cowpea [Vigna unguiculata (L.) walp.]. Legum Res 38:121-125

Kumar J, Pundhir VS (2009) Recent advances in biological control of plant diseases. Proceeding of 22nd Training of Centre of Advanced Studies in Plant Pathology, College of Agriculture, Pantnagar, pp 194

Kumar S, Mukerji KG, Lai R (1996) Molecular aspects of pesticide degradation by microorganisms. Crit Rev Microbiol 22:1-26

Kumar V, Shriram V, Hossain MA, Kishor PK (2015) Engineering proline metabolism for enhanced plant salt stress tolerance. In: Wani SH, Hossain MA (eds) 
Managing salt tolerance in plants: molecular and genomic perspectives. CRC Press, Boca Raton, pp 353-372

Lacey LA, Shapiro-Ilan DI (2008) Microbial control of insect pests in temperate orchard systems: potential for incorporation into IPM. Annu Rev Entomol 53:121-144

Letreme P (2002) Recommendations by health organizations for pulse consumption. Br J Nutr 88:S239-S242

Martinez-Toledo MV, Salmeron V, Rodelas B, Pozo C, Gonzalez-Lopez J (1996) Studies on the effects of the herbicide simazine on microflora of four agricultural soils. Environ Toxicol Chem 15:1115-1118

Mathur SC (1999) Future of Indian pesticides industry in next millennium. Pestic Inf 24:9-23

Matsunaga R, Singh BB, Adamou M, Tobita S, Hayashi K, Kamidohzono A (2008) Yield performance, nitrogen and phosphorous acquisition of cowpea germplasm accessions in low-fertility sandy soils in the Sahelian Zone. Trop Agric Dev 52:50-57

Maxted N, Ford-Lloyd BV, Jury S, Kell S, Scholten M (2006) Towards a definition of crop wild relatives. Biodivers Conserv 15:2673-2685

Moorma TB (1988) A review of pesticide effects on microorganisms and microbial processes related to soil fertility. J Prod Agric 2:14-23

Muthezhilan R, Sindhuja BS, Hussain AJ, Jayaprakash M (2012) Efficiency of plant growth-promoting rhizobacteria isolated from Sand Dunes of Chennai costal area. Pak J Biol Sci 15:795-799

Nair RM, Yang RY, Easdown WJ, Thavarajah D, Thavarajah P, Hughes JDA, Keatinge JDHD (2013) Biofortification of mung bean (Vigna radiata) as a whole food to enhance human health. J Sci Food Agric 93:1805-1813

Nene YL (2006) Indian pulses through the millennia. Asian Agri-Hist 10:179-202

Palaniyandi SA, Yang SH, Zhang L, Suh JW (2013) Effects of actinobacteria on plant disease suppression and growth promotion. Appl Microbiol Biotechnol 97:9621-9636

Penrose DM, Glick BR (2003) Methods for isolating and characterizing ACC deaminase-containing plant growthpromoting rhizobacteria. Physiol Plant 118:10-15

Peoples MB, Crasswell ET (1992) Biological nitrogen fixation: investments, expectations and actual contributions to agriculture. Plant Soil 141:13-39

Rajkumar M, Ae N, Prasad MNV, Freitas H (2010) Potential of siderophore-producing bacteria for improving heavy metal phytoextraction. Trends Biotechnol 28:142-149

Rubiales D, Fondevilla S, Chen W, Gentzbittel L, Higgins TJV, Castillejo MA, Singh KB, Rispail N (2015) Achievements and challenges in legume breeding for pest and disease resistance. Crit Rev Plant Sci 34:1-42

Sahu GK, Sindhu SS (2011) Disease control and plant growth-promotion of green gram by siderophore producing Pseudomonas sp. Res J Microbiol 6:735-749

Saxena MJ (2010) Disease suppression and crop improvement in moong beans (Vigna radiata) through
Pseudomonas and Burkholderia strains isolated from semi-arid region of Rajasthan, India. BioControl 55: 799-810

Saxena NC (2011) Hunger, under-nutrition and food security in India CPRC-IIM Working paper 44, 23, pp 1-65. www.dfid.gov.uk/r4d/PDF/Outputs/...RC/ CPRC-IIPA44.pdf

Sehrawat N, Yadav M, Bhat KV, Sairam RK, Jaiwal PK (2015) Effect of salinity stress on mung bean [Vigna radiata (L.) wilczek] during consecutive summer and spring seasons. J Agric Sci 60:23-32

Shahab S, Ahmed N, Khan NS (2009) Indole acetic acid production and enhanced plant growth-promotion by indigenous PSBs. Afr J Agric 4:1312-1316

Shaharoona B, Arshad M, Zahir ZA (2006) Effect of plant growth-promoting rhizobacteria containing ACC-deaminase on maize (Zea mays L.) growth under axenic conditions and on nodulation in mung bean (Vigna radiata L.). Lett Appl Microbiol 42:155-159

Sharma A, Johri BN (2003) Combat of iron-deprivation through a plant growth-promoting fluorescent Pseudomonas strain GRP3A in mung bean (Vigna radiata L. Wilzeck). Microbiol Res 158:77-81

Sharma A, Johri BN, Sharma AK, Glick BR (2003) Plant growth-promoting bacterium Pseudomonas sp. strain GRP3 influences iron acquisition in mung bean (Vigna radiata L. Wilzeck). Soil Biol Biochem 35:887-894

Siddiqui ZA, Mahmood I (1999) Role of bacteria in the management of plant parasitic nematodes: a review. Bioresour Technol 69:167-179

Sindhu SS, Gupta SK, Dadarwal KR (1999) Antagonistic effect of Pseudomonas spp. on pathogenic fungi and enhancement of growth of green gram (Vigna radiata). Biol Fertil Soils 29:62-68

Singh BB (2005) Cowpea [Vigna unguiculata (L.) Walp.]. In: Singh RJ, Jauhar PP (eds) Genetic resources, chromosome engineering, and crop improvement, vol 1, Grain legumes. Taylor \& Francis, Boca Raton, pp 117-161

Singh D, Pal M, Singh R, Singh CK, Chaturvedi AK (2015) Physiological and biochemical characteristics of Vigna species for Al stress tolerance. Acta Physiol Plant 37:87

Sivakumar T, Ravikumar M, Prakash M, Thamizhmani R (2013) Comparative effect on bacterial biofertilizers on growth and yield of green gram (Phaseolus radiata L.) and cow pea (Vigna siensis Edhl.). Int J Curr Res Acad Rev 1(2):20-28

Swaminathan M (1974) Pulses - essentials of food and nutrition. Ganesh and Co., Madras

Thilagavathi R, Saravanakumar D, Ragupathi N, Samiyappan R (2007) A combination of biocontrol agents improves the management of dry root rot (Macrophomina phaseolina) in green gram. Phytopathol Mediterr 46:157-167

Thulin M, Lavin M, Pasquet R, Delgado-Salinas A (2004) Phylogeny and biogeography of Wajira (Leguminosae): a monophyletic segregate of Vigna centered on the Horn of Africa region. Syst Bot 29:903-920 
Tomooka N, Vaughan DA, Kaga A (2005) Mung bean. In: Singh RJ, Jauhar PP (eds) Genetic resources, chromosome engineering and crop improvement. II. Grain legumes. CRC, Boca Raton, pp 319-339

Tomooka N, Kaga A, Vaughan DA (2006) The Asian Vigna (Vigna subgenus Ceratotropis) biodiversity and evolution. In: Sharma AK, Sharma A (eds) Plant genome: biodiversity and evolution. Part C: phanerogams (angiosperms- dicotyledons), vol 1. Science, Enfield, pp 87-126

Tomooka N, Kaga A, Isemura T, Vaughan D (2011) Vigna. In: Kole C (ed) Wild crop relatives: genomic and breeding resources. Springer, Berlin/Heidelberg, pp 291-311

Uchiumi T, Oowada T, Itakura M, Mitsui H, Nukui N, Dawadi P, Kaneko T, Tabata S, Yokoyama T, Tejima T, Saeki K, Oomori H, Hayashi M, Maekawa T, Sriprang R, Murooka Y, Tajima S, Simomura K, Nomura M, Suzuki A, Shimoda S, Sioya K, Abe M, Minamisawa K (2004) Expression islands clustered on symbiosis island of Mesorhizobium loti genome. J Bacteriol 186:2439-2448

Ullah R, Ullah Z, Al-Deyab SS, Adnan M, Tariq A (2014) Nutritional assessment and antioxidant activities of different varieties of Vigna radiata. Sci World J 2014:871753. doi:10.1155/2014/871753

Uren NC (2007) Types, amounts, and possible functions of compounds released into the rhizosphere by soilgrown plants. In: Pinton R, Varanini Z, Nannipieri P (eds) The rhizosphere: biochemistry and organic substances at the soil-plant interface. CRC Press, Boca Raton, pp 1-22

Vaillancourt RE, Weeden NF, Bruneau A, Doyle JJ (1993) Chloroplast DNA phylogeny of old world Vigna (Leguminosae). Syst Bot 18:642-651
Vaishali AP, Pooja RP, Ashok MB, Sourabh VC (2014) Effect of Rhizobium on seed germination and growth of plants. J Acad Ind Res 3(2):84-88

Vassilev N, Vassileva M, Nikolaeva I (2006) Simultaneous P-solubilizing and biocontrol activity of microorganisms: potentials and future trends. Appl Microbiol Biotechnol 71:137-144

Vessey KJ (2003) Plant growth-promoting rhizobacteria as biofertilizers. Plant Soil 255:571-586

Vijayakumari K, Siddhuraju P, Pugalenthi M, Janardhanan K (1998) Effect of soaking and heat processing on the levels of antinutrients and digestible proteins in seeds of Vigna aconitifolia and Vigna sinensis. Food Chem 63:259-326

Vikram A, Hamzehzarghani H (2008) Effect of phosphate solubilizing bacteria on nodulation and growth parameters of green gram (Vigna radiate L.Wilczek). Res J Microbiol 3:62-72

Walpola BC, Yoon M (2013) Phosphate solubilizing bacteria: assessment of their effect on growth-promotion and phosphorous uptake of mung bean (Vigna radiata [L.] R. Wilczek). Chil J Agric Res 73:275-281

Walters KS, Gillet HJ (1998) 1997 IUCN Red list of threatened plants. Compiled by the world conservation monitoring centre. IUCN - The World Conservation Union, Gland

Win KT, Zaw A, Hirasawa T, Ookawa T, Yutaka H (2011) Genetic analysis of Myanmar Vigna species in responses to salt stress at the seedling stage. Afr J Biotechnol 10:1615-1624

Zaidi A, Khan MS (2006) Co-inoculation effects of phosphate solubilizing microorganisms and Glomus fasciculatum on green gram-Bradyrhizobium symbiosis. Turk J Agric For 30:223-230 